\title{
FAKTOR PENGARUH LINGKUNGAN KERJA DAN DISIPLIN KERJA TERHADAP KONTRIBUSI KINERJA KARYAWAN PADA PT. GAPURA ANGKASA BANDARA SOEKARNO HATTA
}

\author{
Novi Cholisoh ${ }^{1}$ \\ Sendy Zul Friandi ${ }^{2}$ \\ Grees Wiliam $^{3}$ \\ Dosen AMIK Raharja Informatika ${ }^{1}$, Dosen STMIK Raharja ${ }^{2}$, Mahasiswa STMIK Raharja Teknik \\ Informatika ${ }^{3}$ \\ Jl. Jendral Sudirman No. 40, Modern Cikokol, Tangerang \\ Email : novi@ raharja.info ${ }^{1)}$, sendy@raharja.info ${ }^{21}$, grees.wiliam@ raharja.info $^{31}$
}

\begin{abstract}
ABSTRAK
Manajemen adalah sebuah bentuk bekerja dengan orang-orang atau tim untuk mencapai tujuan organisasi dengan pelaksanaan perencanaan (planning), pengorganisasian (organizing), penyusunan personalia ataupun kepegawaian (staffing), pengarahan dan kepemimpinan (leading), serta pengawasan (controlling). perencanaan, pengorganisasian, penggerakan, dan pengendalian yang dilakukan untuk menentukan serta mencapai sasaransasaran yang telah ditentukan melalui pemanfaatan sumber daya manusia dan sumber daya lainnya. PT. Gapura Angkasa merupakan salah satu perusahaan Ground Handling yang mengutamakan kepuasan dan loyalitas konsumen dimana konsumennya adalah pihak maskapai penerbangan asing maupun domestik di seluruh Indonesia dan untuk meningkatkan keuntungan kemajuan terhadap perusahaan tersebut serta tidak terlepas dari peran sumber daya manusia berkualitas serta peran sumber daya manusia berdisiplin sangatlah penting dalam kemajuan perusahaan. hasil pengujian (Ujif) ada pengaruh yang positif dan signifikan antara lingkungan kerja terhadap kinerja karyawan PT. Gapura Angkasa Div Load Control sebesar 62.9\% dan sisanya $37.1 \%$ menjelaskan bahwa kinerja karyawan dipengaruhi oleh faktor-faktor lain diluar lingkungan kerja. pengujian hipotesis secara individual (Uji t) diperoleh nilai signfikan yaitu variabel Disiplin Kerja sebesar 0.000 lebih kecil dari 0.05 yang berarti Disiplin Kerja berpengaruh signifikan terhadap Kinerja Karyawan. Dan hasil pengujian (Uji f) ada pengaruh yang positif dan signifikan antara disiplin kerja terhadap kinerja karyawan PT. Gapura Angkasa Div Load Control sebesar $52.5 \%$ dan sisanya $47.5 \%$ menjelaskan bahwa kinerja karyawan dipengaruhi oleh faktorfaktor lain diluar.
\end{abstract}

Kata Kunci : Manajemen Kinerja Karyawan, Disiplin Kerja.

\section{ABSTRACT}

Management is working with people to achieve organizational goals with the implementation of planning (planning), organizing, personnel or staffing, direction and leadership (leading), and controlling. planning, organizing, mobilizing and controlling to determine and achieve targeted goals that have been determined through the utilization of human and other resources. PT Gapura Angkasa is one of the Ground Handling companies that prioritizes customer satisfaction and loyalty where its customers are foreign and domestic airlines throughout Indonesia and to increase the profits of progress towards the company and can not be separated from qualified human resources and the role of human resources discipline is very important in the progress of the company. test results (Test f) there is a positive and significant influence between the work environment on employee performance PT. Gapura Angkasa Div Load Control of 62.9\% and the remaining $37.1 \%$ explained that employee performance is influenced by other factors outside the work environment. testing the hypothesis individually (Test t) obtained the significance value of Work Discipline variable of 0.000 is smaller than 0.05 which means Work Discipline significantly influence Employee Performance. And the test results (Test $f$ ) there is a positive and significant influence between the discipline of work on the performance of employees of PT. Gapura Angkasa Div Load Control of 52.5\% and the remaining 47.5\% explained that employee performance is influenced by other factors the outside.

Keywords: Employee Performance Management, Work Discipline. 


\section{PENDAHULUAN}

Setiap perusahaan di tuntut untuk memiliki manajemen yang baik. Suatu manajemen perusahaan yang baik pasti dapat meningkatkan efektifitas perusahaan. Efektifitas suatu perusahaan dapat tercapai dengan baik sehingga mampu untuk bersaing dengan perusahaan lainnya. Seperti sumber daya manusia yang merupakan salah satu factor penting dan memiliki peran yang besar dalam suatu perusahaan.

Selain mengolah berbagai sumber daya yang dimiliki perusahaan seperti modal, material, dan mesin untuk mempasilitasi capaian tujuan perusahaan. Perusahaan juga membutuhkan sumber daya manusia yaitu para karyawan. Karyawan merupakan sumber daya yang penting bagi perusahaan karena memiliki bakat, tenaga dan kreatifitas yang sangat dibutuhkan oleh perusahaan. Relevansi dan pentingnya manajemen sumber daya manusia tidak terlepas dari berbagai perkembangan dan kemajuan yang dicapai di bidang ilmu pengetahuan dan teknologi (IPTEK). Dampak dari berbagai kemajuan tersebut dapat bersifat positif dan juga bisa negatif.

Lingkungan kerja mempunyai pengaruh terhadap kinerja karyawan perusahaan, dalam usaha untuk menyelesaikan tugas-tugas yang di bebankan kepada karyawan yang akhirnya bepengaruh terhadap kinerja kayawan, lingkungan yang baik akan meningkatkan kinerja karyawan, begitu juga sebaliknya apabila lingkungan kerja kurang tenang maka akan mempertinggi tingkat kesalahan yang mereka lakukan dan berakibat fatal pada perusahaan itu sendiri. Hasibuan (2013;23). PT. Gapura Angkasa merupakan salah satu perusahaan Ground Handling yang mengutamakan kepuasan dan loyalitas konsumen dimana konsumennya adalah pihak maskapai penerbangan asing maupun domestik di seluruh Indonesia dan untuk meningkatkan keuntungan kemajuan terhadap perusahaan. tidak hanya itu sikap disiplin akan dapat mendorong semangat kerja demi terwujudnya keberhasilan di perusahaan tersebut. Keberhasilan dalam mengembangkan kewajiban-kewajiban sangat tergantung ada kesediaanya untuk berkorban dan berkerja keras serta mengutamakan keselamatan juga. Peningkatan kinerja melalui disiplin kerja yang baik merupakan suatu hal yang sangat di butuhkan dalam sebuah organisasi perusahaan.

\section{RUMUSAN MASALAH}

1. Adakah kontribusi lingkungan kerja terhadap kinerja karyawan di PT Gapura Angkasa?

2. Adakah kontribusi disiplin kerja terhadap kinerja karyawan di PT Gapura Angkasa?

3. Apakah secara bersama-sama kontribusi lingkungan kerja dan disiplin kerja terhadap kinerja berpengaruh terhadap karyawan di PT Gapura Angkasa?

\section{BATASAN MASALAH}

Berdasarkan latar belakang masalah yang telah di kemukakan di atas maka dalam penelitian dan pembahasan ini penulis mengidentifikasikan kontribusi lingkungan kerja dan disiplin kerja terhadap kinerja karyawan di PT Gapura Angkasa sebagai berikut: 
1. Variabel yang di teliti adalah kontribusi lingkungan kerja dan disiplin kerja terhadap kinerja karyawan.

2. Obyek penelitian adalah di PT Gapura Angkasa Bandara Soekarno-Hatta DIV Load Control.

3. Penulis hanya meneliti beberapa karyawan dengan menggunakan rumus tertentu.

\section{HIPOTESIS}

Hipotesis alternatif yang diajukan adalah Sebagai Berikut :

"Diduga kontribusi lingkungan kerja dan disiplin karyawan secara simultan berpengaruh secara positif dan signifikan terhadap kualitas kinerja karyawan pada PT. Gapura Angkasa Divisi Load Control"

\section{KERANGKA PEMIKIRAN}

Dalam penelitian akan menguji pengaruh faktor - faktor lingkungan kerja dan disiplin karyawan apabila kedua faktor tersebut di berlakukan masing - masing maupun secara bersamaan terhadap karyawan PT. Gapura Angkasa Divisi Load Control. Dalam memberikan gambaran mengenai pokok pikiran pada penelitian secara skematis kerangka pemikiran penelitian sebagai berikut :

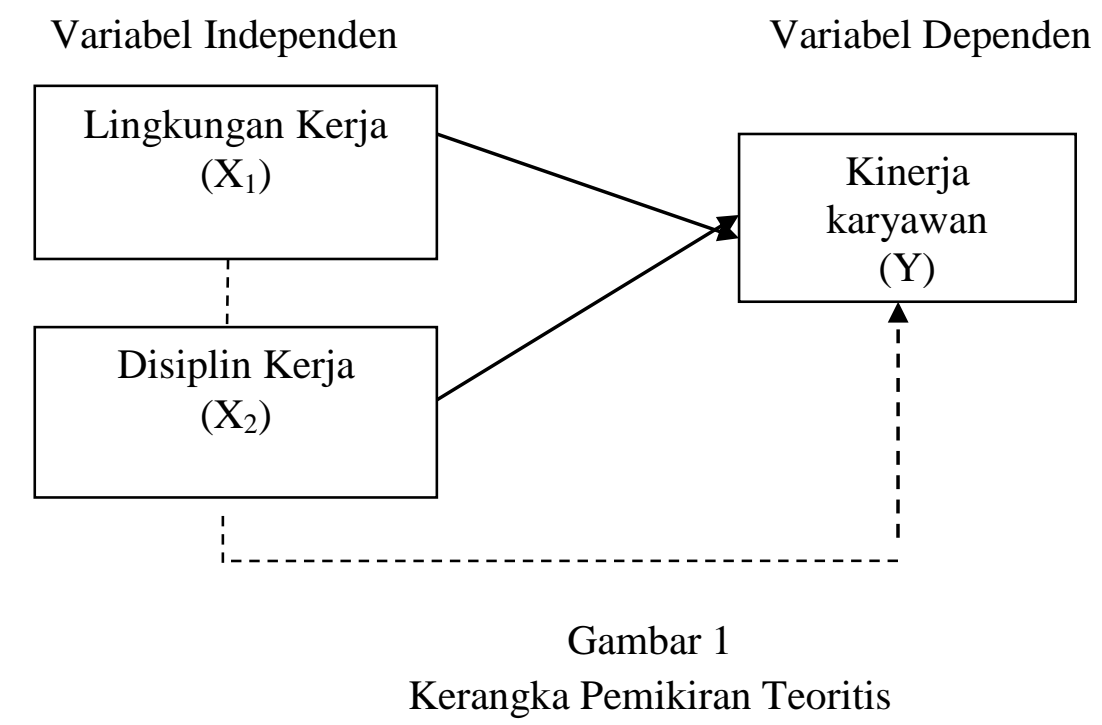

Alur Skema Kerangka Pemikiran diatas:

1. Pengaruh Lingkungan Kerja terhadap Kinerja Karyawan $\mathrm{X}_{1} \rightarrow \mathrm{Y}$

2. Pengaruh Disiplin Kerja Terhadap Kinerja Karyawan $\mathrm{X}_{2} \rightarrow \mathrm{Y}$

3. Pengaruh Lingkungan Kerja Disiplin Kerja Terhadap Kinerja Karyawan $\mathrm{X}_{1} \rightarrow \mathrm{Y}$ $\mathrm{X}_{2} \rightarrow \mathrm{Y}$ 


\section{LITERATUR REVIEW}

Literature Review ini dilakukan oleh peneliti untuk mengetahui landasan awal dan sebagai pendukung bagi kegiatan penelitian yang dilakukan oleh peneliti, sehingga dapat menghindari pengulangan hal yang sama dalam penelitian dan dapat melakukan pengembangan ketingkat yang lebih tinggi dalam rangka menyempurnakan atau melengkapi penelitian yang nantinya di kembangkan lagi kedepannya.

Adapun Literature Review sebagai berikut :

1. Penelitian yang dilakukan Muhammad Tri Aji Sudrajat dkk. tentang "Pengaruh Lingkungan Kerja Terhadap Kinerja Karyawan pada Divisi Load Control Tahun 2015"

2. Penelitian yang dilakukan Hendra Wahyu Kurniawan dkk tentang "Pengaruh Disiplin Kerja Terhadap Kinerja Dalam Menentukan Kualitas Kinerja Karyawan Di Toserba Griya Cicalengka Tahun 2013"

3. Peneletian yang dilakukan oleh Rini Kundaryati. Dkk. Yaitu hubungan Antara pendidikan dan Sumber Informasi Dengan Tingkat Pengetahuan ibu Tentang Post Partum Blues di RB Ratna Komala Bekasi Jawa Barat.

\section{METODELOGI PENELITIAN}

Penelitian ini menggunakan pola pendekatan kuantitatif. Sebagaimana di jelaskan Arikunto $(2015 ; 10)$, penelitian kuantitatif merupakan penelitian yang dalam prosesnya banyak menggunakan angka-angka dari mulai pengumpulan data, penafsiran terhadap olahan data, serta penampilan data dari hasilnya.

Adapun rumusan metodelogi yang digunakan dalam penelitian ini adalah sebagai berikut :

\section{Pengukuran Variabel}

(Sugiyono, 2014). Pengukuran variabel adalah meletakkan arti pada suatu variabel dengan cara menetapkan kegiatan atau tindakan yang perlu untuk mengukur variabel itu. Pengertian operasional variabel ini kemudian diuraikan menjadi indikator empiris yang meliputi :

\begin{tabular}{|c|l|c|}
\hline Variabel & \multicolumn{1}{|c|}{ Indikator } & Item \\
\hline Lingkungan & a. Suasana kerja & 1,2 \\
\cline { 2 - 3 } kerja (X1) & b. Tersedianya fasilitas kerja & 3,4 \\
\hline & c. Kebisingan di tempat kerja. & 5,6 \\
\hline & $\begin{array}{l}\text { d. } \begin{array}{l}\text { Penerangan cahaya di tempat } \\
\text { kerja. }\end{array} \\
\end{array}$ & 7,8 \\
\hline & e. Keamanan di tempat kerja & 9,10 \\
\hline
\end{tabular}




\begin{tabular}{|c|l|c|}
\hline & & \\
\hline \multirow{2}{*}{$\begin{array}{c}\text { Disiplin Kerja } \\
(\mathbf{X} 2)\end{array}$} & a. Sikap & $11,12,13$ \\
\hline & b. Norma & $14,15,16$ \\
\hline & c. Tanggung jawab & $17,18,19,20$ \\
\hline \multirow{2}{*}{$\begin{array}{c}\text { Kinerja } \\
\text { Karyawan (Y) }\end{array}$} & a. Tugas & 21,22 \\
\hline & b. Jam kerja & $23,24,25$ \\
\hline & c. Kehadiran & $26,27,28$ \\
\hline & d. Kerjasama anta karyawan & 29,30 \\
\hline
\end{tabular}

\section{Tabel 1}

Pengukuran Variabel Penelitian

\section{Analisis dan Validasi Data}

(Ridwan dan Kuncoro,2014:38) Uji coba secara empirik menggunakan korelasi product moment dengan bantuan fasilitas computer program Statistical Programe and Service Solutions (SPSS) Versi 21 for windows. Dasar pengambila keputusan dalam uji validitas adalah sebagai berikut:

1. Apabila nilai $t_{\text {hitung }}$ negatif dan $t_{\text {hitung }}>t_{\text {tabel }}$ maka butir atau variabel tersebut valid.

2. Apabila nilai $t_{\text {hitung }}$ negatif dan $t_{\text {hitung }}<t_{\text {tabel }}$ ataupun $t_{\text {hitung }}$ negatif $>r_{\text {tabel }}$ maka butir atau variabel tersebut tidak valid.

Adapun rumus korelasi product moment (Edi Riadi, 2014:141) untuk mencari nilai $r_{\text {hitung }}$ atau validitas sebagai berikut:

$$
r_{x y=} \frac{n\left(\sum X Y\right)-\left(\sum X\right)\left(\sum Y\right)}{\sqrt{\left[n\left(\sum X^{2}\right)-\left(\sum X\right)^{2}\right]\left[n\left(\sum Y^{2}\right)-\left(\sum Y\right)^{2}\right]}}
$$

Dimana :

$\begin{array}{ll}\mathrm{r}_{\mathrm{xy}} & \text { : koefisien korelasi antara } \mathrm{X} \text { dan } \mathrm{Y} \\ \Sigma \mathrm{XY} & : \text { Jumlah perkalian antara } \mathrm{X} \text { dan } \mathrm{Y} \\ \Sigma \mathrm{X} & : \text { Jumlah kuadrat } \mathrm{X} \\ \Sigma \mathrm{Y} & : \text { Jumlah kuadrat } \mathrm{Y} \\ n & : \text { Jumlah sampel (banyaknya data) }\end{array}$

suatu kuesioner dinyatakan valid apabila nilai $\mathrm{r}$ yang diperoleh dari hasil perhitungan (rxy) lebih besar daripada $r$ tabel dengan taraf signifikan 5\%.

\section{Uji Hipotesis}

Regresi Linear Sederhana yaitu untuk memprediksi atau memperkirakan nilai variabel dependen dalam hubungannya dengan variabel independen. 


$$
\mathrm{Y}=\mathrm{a}+\mathrm{bX}
$$

Gambar 2. Sumber : Sugiyono (2014 : 188)

Keterangan :

$\mathrm{Y}^{\prime} \quad$ : Variabel dependen sebagai variabel yang diduga/ diprediksi

$\mathrm{X} \quad$ : Variabel independet, nilai variabel yang diketahui

a : Konstanta atau nilai $\mathrm{X}=0$

b : Koefisien regresi

Regresi Linear Berganda Yaitu dilakukan untuk meniliti apakah ada korelasi sebab akibat antara kedua variabel atau meneliti seberapa besar pengaruh antara variabel independen, yaitu lingkungan dan disiplin kerja terhadap variabel dependen yaitu kinerja karyawan di PT Gapura Angkasa DIV Load Control. Adapun rumus yang digunakan:

$$
Y=a+\beta_{1} X_{1}+\beta_{2} X_{2}+e
$$

Gambar 3. Sumber : Sugiyono (2014 : 188)

Dimana :

$\begin{array}{ll}\mathrm{Y} & \text { : Kinerja Karyawan } \\ \mathrm{X} 1 & \text { : Lingkungan Kerja } \\ \mathrm{X} 2 & \text { : Disiplin Kerja } \\ \mathrm{a} & \text { : Bilangan konstanta } \\ \mathrm{e} & \text { : error yang ditolerir }(10 \%)\end{array}$

\section{Korelasi}

Korelasi Sederhana Untuk mengetahui signifikan tidaknya hubungan variabel independen dengan variabel dependent. Dengan rumus sebagai berikut :

$$
\mathrm{r}_{\chi Y}=\frac{\mathrm{n} \sum \mathrm{XY}-\sum \mathrm{X} \sum \mathrm{Y}}{\sqrt{\left\{n \sum X^{2}-\left(\sum X^{2}\right)\right\}\left\{n \sum Y^{2}-\left(\sum Y\right)^{2}\right.}}
$$

Gambar 3. Sumber : Sugiyono (2014: 280)

Keterangan :

$\mathrm{r} \quad=$ Koefisien korelasi sederhana

$\mathrm{X} \quad=$ Variabel bebas $\left(\mathrm{X}_{1}\right.$ dan $\left.\mathrm{X}_{2}\right)$

$\mathrm{Y} \quad=$ Variabel tidak bebas $(\mathrm{Y})$

Untuk Korelasi Berganda yang melibatkan lebih dari dua variabel, teknik statistik yang digunakan adalah koefisien korelasi berganda, koefisien parsial, dan koefisien determinasi. Koefisien korelasi berganda (multiple correlation) diberi 
simbol $\mathrm{R}$ adalah angka yang menunjukkan arah dan kerekatan hubungan dan membuktikan hipotesis hubungan antara dua atau lebih variabel independen $\left(\mathrm{X}_{1}, \mathrm{X}_{2}\right.$, ... $\mathrm{X}_{1}$ ) secara simultan atau secara bersama-sama dengan satu variabel dependen (Y). Skala data dari masing-masing variabel tersebut berbentuk skala interval atau skala rasio (termasuk teknik statistik parametris).Rumus untuk menghitung nilai korelasi berganda sebagai berikut:

$$
\mathrm{R}=\sqrt{\frac{r_{\gamma \chi}^{2}+r_{\gamma \chi 2}^{2}-2 r_{\gamma \chi 1} r_{1 \gamma \chi 2} r_{\chi 1 \chi 2}}{1-r_{\chi 1 \chi 2}^{2}}}
$$

Gambar 4. Sumber : Sugiyono (2014 : 234)

Keterangan :

$\mathrm{R} \quad$ : Koefisien korelasi berganda antara $\mathrm{X}_{1}$ dan $\mathrm{X}_{2}$ secara simultan (bersama-sama) dengan $\mathrm{Y}$

$\mathrm{r}_{\mathrm{yx}_{1}} \quad:$ Koefisien korelasi Pearson antara $\mathrm{X}_{1}$ dengan $\mathrm{Y}$

$\mathrm{r}_{\mathrm{xy}_{2}} \quad$ : Koefisien Korelasi Pearson antara $\mathrm{X}_{2}$ dengan $\mathrm{Y}$

$\mathrm{r}_{\mathrm{x}_{1} \mathrm{x}_{2}} \quad$ : Koefisien Korelasi Pearson antara $\mathrm{X}_{1}$ dengan $\mathrm{X}_{2}$

\section{Uji $\mathbf{R}^{2}$ (Koefisien determinasi)}

Koefisien Determinasi juga disebut koefisien penentu adalah kuadrat dari nilai koefisien korelasi artinya perubahan variabel dependen (variabel Y) yang disebabkan variabel independen (variabel $\mathrm{X}$ ) adalah sebesar kuadrat koefisien korelasi $\left(\mathrm{r}^{2}\right)$. Koefisien determinasi ini menjelaskan besarnya presentase pengaruh variabel $\mathrm{X}$ terhadap naik-turunnya nilai variabel $\mathrm{Y}$, sedangkan sisanya atau selisihnya dari $100 \%$ adalah pengaruh yang disebabkan oleh faktor lainnya yang tidak diteliti. Nilai koefisien determinasi terletak antara 0 dan 1 atau dinotasikan $0 \leq \mathrm{KD} \leq 1$, dengan rumus sebagai berikut:

$$
K D=r^{2} \times 100 \%
$$

Gambar 5. Sumber : Ridwan (2015 : 228)

Keterangan :

KD : Koefisien determinasi

r : :Koefisien korelasi

\section{Uji parsial (uji t)}

Adapun cara untuk menguji dari hipotesis yang ada dengan uji t. pengujian ini dimaksudkan untuk mengetahui apakah dua indikator variable tersebut secara bersamaan mempunyai pengaruh yang signifikan terhadap variable Y. Rumus uji $t$ yang digunakan adalah :

$$
t=\frac{\mathrm{r} \sqrt{\mathrm{n}-2}}{\sqrt{1-\mathrm{r}^{2}}}
$$


Gambar 6. Sumber: (Priyatno : 2018)

Langkah-langkah pengujian terhadap koefisien regresi adalah sebagai berikut :

a. Ho : $\beta=0$, ada pengaruh yang signifikan antara variable $\mathrm{X}_{1}$ terhadap $\mathrm{Y}$.

b. Ha : $\beta \neq 0$, tidak ada pengaruh yang signifikan antara variable $X_{1}$ terhadap Y.

c. Ho : $\beta=0$, tidak ada pengaruh yang signifikan terhadap variable $\mathrm{X}_{2}$ terhadap variable $Y$.

d. Ha : $\beta=0$, ada pengaruh yang signifikan antara variable $\mathrm{X}_{2}$ terhadap variable Y.

e. Dalam pengujian digunakan taraf signifikasi sebesar $5 \%$ dan derajat kebebasan $(\mathrm{d} . \mathrm{f})=(\mathrm{k}-1, \mathrm{n}-\mathrm{k}, \alpha)$, diketahui hasil dari perhitungan computer program SPSS- 21.

Kesimpulan yang diambil adalah jika $t_{\text {hitung }}>t_{\text {tabel }}$ maka Ho ada didaerah penolakan, berarti Ha diterima artinya variable $\mathrm{X}$ dan variable $\mathrm{Y}$ terdapat pengaruh. Jika $t_{\text {hitung }}<t_{\text {tabel }}$, maka Ho ada didaerah penerimaan, berarti Ha ditolak antara variable $\mathrm{X}$ dan variable $\mathrm{Y}$ tidak ada hubungannya.

\section{Uji simultan (uji f)}

Pengujian ini digunakan untuk mengetahui besaran pengaruh variable bebas terhadap variable terikat, yaitu apakah $X_{1}$ dan $X_{2}$ yang secara bersamaan berpengaruh terhadap variable $\mathrm{Y}$. Adapun rumusnya sebagai berikut :

$$
\mathrm{Fh}=\frac{\mathrm{R}^{2} / \mathrm{k}}{\left(1-R^{2}\right) /(\mathrm{n}-\mathrm{k}-1)}
$$

Gambar 7. Sumber : Sugiyono (2014 : 192)

Dimana :

R : Koefisien Korelasi berganda

$\mathrm{k}$ : Jumlah variable independen

n : Jumlah anggota sampel

Kriteria untuk menguji hipotesis adalah:

a. Membuat hipotesis untuk kasus pengujian F_test tersebut, adalah:

- Ho : $\beta=0$, artinya tidak ada pengaruh $\mathrm{X}_{1}, \mathrm{X}_{2}$ terhadap $\mathrm{Y}$.

- Ho : $\beta \neq 0$, artinya ada pengaruh $\mathrm{X}_{1}, \mathrm{X}_{2}$ terhadap $\mathrm{Y}$.

b. Menentukan $F_{\text {tabel }}$ dan $F_{\text {hitung }}$

c. Tingkat kepercayaan sebesar $95 \%$ atau taraf signifikasi sebesar 5\%, maka:

- Jika $F_{\text {hitung }}>F_{\text {tabel, }}$ maka Ho diterima dan Ha ditolak.

- Jika $F_{\text {hitung }}<\mathrm{F}_{\text {tabel }}$, maka Ho ditolak dan Ha diterima 


\section{HASIL PENGUJIAN DAN PEMBAHASAN}

\section{Karakteristik Responden Penelitian}

Sebelum msuk dalam tahap pengujian, terlebih dahulu dikemukakan gambaran karakteristik-karakteristik responden, yang tujuannya untuk menampilkan informasi keadaan responden berdasarkan jenis kelamin, usia, pendidikan terakhir. Berdasarkan hasil pengumpulan data yang diperoleh melalui kuesioner yang disebarkan kepada karyawan PT. Gapura Angkasa, diperoleh data profil responden sebagai berikut :

a. Responden Berdasarkan Jenis Kelamin

Tabel 1

Responden Berdasarkan Jenis Kelamin

\begin{tabular}{|c|c|c|c|}
\hline No & $\begin{array}{c}\text { Jenis } \\
\text { kelamin }\end{array}$ & $\begin{array}{c}\text { Jumlah } \\
\text { responden }\end{array}$ & $\begin{array}{c}\text { Presentase } \\
(\mathbf{\%})\end{array}$ \\
\hline 1 & Laki-laki & 38 & 79,2 \\
\hline 2 & Perempuan & 10 & 20,8 \\
\hline \multicolumn{2}{|c|}{ Jumlah } & 48 & 100 \\
\hline
\end{tabular}

Sumber: Hasil Olah Data SPSS 21

sebagian besar responden laki-laki sebanyak 38 orang atau sekitar 79,2\%, sedangkan responden perempuan sebanyak 10 orang atau $20,8 \%$.

b. Responden Berdasarkan Usia

Tabel 2

Responden Berdasarkan Usia

\begin{tabular}{|c|c|c|c|}
\hline No & Usia & $\begin{array}{c}\text { Jumlah } \\
\text { responden }\end{array}$ & $\begin{array}{c}\text { Presentase } \\
(\boldsymbol{\%})\end{array}$ \\
\hline 1 & $20-25$ th & 4 & 8,3 \\
\hline 2 & $26-30$ th & 25 & 52,1 \\
\hline 3 & $31-40$ th & 14 & 29,2 \\
\hline 4 & $41-55$ th & 5 & 10,4 \\
\hline \multicolumn{2}{|c|}{ Jumlah } & 48 & 100 \\
\hline
\end{tabular}

Sumber: Hasil Olah Data SPSS 21

responden yang berusia 20-25 tahun berjumlah 4 orang atau 8,3. Responden yang berusia 26-30 tahun berjumlah 25 orang atau 52,1\%. Responden yang berusia 31-40 tahun berjumlah 14 orang atau 29,2\% dan responden yang berusia 41-55 tahun berjumlah 5 orang atau $10,4 \%$.

c. Responden Berdasarkan Pendidikan Terakhir

Tabel 3

Responden Berdasarkan Pendidikan Terakhir 


\begin{tabular}{|c|c|c|c|}
\hline No & $\begin{array}{c}\text { Pendidikan } \\
\text { terakhir }\end{array}$ & $\begin{array}{c}\text { Jumlah } \\
\text { Responden }\end{array}$ & $\begin{array}{c}\text { Presentase } \\
(\mathbf{\%})\end{array}$ \\
\hline 1 & SMA/SMK & 13 & 27,1 \\
\hline 2 & Diploma & 10 & 20,8 \\
\hline 3 & S1 & 25 & 52,1 \\
\hline \multicolumn{2}{|c|}{ Jumlah } & 48 & 100 \\
\hline
\end{tabular}

Sumber: Hasil Olah Data SPSS 21

Sebagian responden dengan pendidikan terakhir minimal SMA/SMK sejumlah 13 orang atau $27,1 \%$, yang berpendidikan diploma berjumlah 10 orang atau 20,8\%, dan yang berpendidikan $\mathrm{S} 1$ berjumlah 25 orang atau 52,1\%. Dengan demikian responden dengan latar belakang pendidikan S1 sebanyak 25 orang atau 52,1\% cukup kreatif dan inovatif dan akan berdampak baik bagi kinerja perusahaan.

\section{d. Responden Berdasarkan Masa Kerja}

\section{Tabel 4}

Responden Berdasarkan Masa Kerja

\begin{tabular}{|c|c|c|c|}
\hline No & Masa kerja & $\begin{array}{c}\text { Jumlah } \\
\text { Responden }\end{array}$ & $\begin{array}{c}\text { Presentase } \\
(\mathbf{\%})\end{array}$ \\
\hline 1 & 0bln-5 tahun & 29 & 60,4 \\
\hline 2 & $6-10$ tahun & 13 & 27,1 \\
\hline 3 & $>11$ tahun & 6 & 12,5 \\
\hline \multicolumn{2}{|c|}{ Jumlah } & 48 & 100 \\
\hline
\end{tabular}

Sumber: Hasil Olah Data SPSS 21

Berdasarkan Tabel diatas menunjukan bahwa sebagian besar responden dengan masa kerja 0-5 tahun berjumlah 29 orang atau 60,4\%, dan masa kerja 6-10 tahun berjumlah 13 orang atau $27,1 \%$. Sedangkan dengan masa kerja $>11$ tahun berjumlah 6 orang atau $12,5 \%$.

\section{Uji Validitas}

Pengujian instrument menggunakan uji dua sisi taraf signifikan 5\%, dengan jumlah responden sebanyak 48 orang maka diketahui nilai $r_{\text {tabel }}(a, n-2)=r_{\text {tabel }}(0.05,46)$ adalah 0,2845 . Adapun kaidah pengujian validitas instrument adalah suatu data dinyatakan valid jika $r_{\text {hitung }}>r_{\text {tabel }}$. Berikut ini hasil pengujian validitas instrument dengan menggunakan program SPSS 21.

a. Variabel Lingkungan Kerja $\left(\mathrm{X}_{1}\right)$

\section{Tabel 5}

Hasil Uji Validitas Variabel Penelitian Lingkungan Kerja $\left(\mathrm{X}_{1}\right)$

\begin{tabular}{|c|c|c|c|}
\hline $\begin{array}{c}\text { No } \\
\text { Pernyataan }\end{array}$ & $\mathbf{r}_{\text {hitung }}$ & $\mathbf{r}_{\text {tabel }}$ & Keterangan \\
\hline 1 & 0,575 & 0.2845 & Valid \\
\hline 2 & 0,346 & 0.2845 & Valid \\
\hline
\end{tabular}




\begin{tabular}{|c|c|c|c|}
\hline 3 & 0,366 & 0.2845 & Valid \\
\hline 4 & 0,301 & 0.2845 & Valid \\
\hline 5 & 0,733 & 0.2845 & Valid \\
\hline 6 & 0,724 & 0.2845 & Valid \\
\hline 7 & 0,575 & 0.2845 & Valid \\
\hline 8 & 0,519 & 0.2845 & Valid \\
\hline 9 & 0,733 & 0.2845 & Valid \\
\hline 10 & 0,724 & 0.2845 & Valid \\
\hline
\end{tabular}

Sumber: Hasil Olah Data SPSS 21

Berdasarkan tabel diatas menunjukkan bahwa item pernyataan valid, karena nilai $r_{\text {hitung }}>r_{\text {tabel }}$ sehingga item pernyataan dapat dimasukkan sebagai pedoman kuesioner.

b. Variabel Disiplin Kerja

Tabel 6

Hasil Uji Validitas Variabel Penelitian Disiplin Kerja $\left(\mathrm{X}_{2}\right)$

\begin{tabular}{|c|c|c|c|}
\hline $\begin{array}{c}\text { No } \\
\text { Pernyataan }\end{array}$ & $\mathbf{r}_{\text {hitung }}$ & $\mathbf{r}_{\text {tabel }}$ & Keterangan \\
\hline 1 & 0.480 & 0.2845 & Valid \\
\hline 2 & 0.827 & 0.2845 & Valid \\
\hline 3 & 0.713 & 0.2845 & Valid \\
\hline 4 & 0.400 & 0.2845 & Valid \\
\hline 5 & 0.374 & 0.2845 & Valid \\
\hline 6 & 0.827 & 0.2845 & Valid \\
\hline 7 & 0.308 & 0.2845 & Valid \\
\hline 8 & 0.827 & 0.2845 & Valid \\
\hline 9 & 0.713 & 0.2845 & Valid \\
\hline 10 & 0.334 & 0.2845 & Valid \\
\hline
\end{tabular}

Sumber: Hasil Olah Data SPSS 21

Berdasarkan tabel diatas menunjukkan bahwa item pernyataan valid, karena nilai $r_{\text {hitung }}>r_{\text {tabels }}$ sehingga item pernyataan dapat dimasukkan sebagai pedoman kuesioner.

c. Variabel kinerja karyawan

Tabel 4.7

Hasil Uji Validitas Variabel Penelitian Kinerja Karyawan (Y)

\begin{tabular}{|c|c|c|c|}
\hline $\begin{array}{c}\text { No } \\
\text { Pernyataan }\end{array}$ & $\mathbf{r}_{\text {hitung }}$ & $\mathbf{r}_{\text {tabel }}$ & Keterangan \\
\hline 1 & 0,478 & 0.2845 & Valid \\
\hline 2 & 0,750 & 0.2845 & Valid \\
\hline
\end{tabular}




\begin{tabular}{|c|c|c|c|}
\hline 3 & 0,316 & 0.2845 & Valid \\
\hline 4 & 0,511 & 0.2845 & Valid \\
\hline 5 & 0,467 & 0.2845 & Valid \\
\hline 6 & 0,750 & 0.2845 & Valid \\
\hline 7 & 0,359 & 0.2845 & Valid \\
\hline 8 & 0,342 & 0.2845 & Valid \\
\hline 9 & 0,478 & 0.2845 & Valid \\
\hline 10 & 0,750 & 0.2845 & Valid \\
\hline
\end{tabular}

Sumber: Hasil Olah Data SPSS 21

Berdasarkan tabel diatas menunjukkan bahwa item pernyataan valid, karena nilai $r_{\text {hitung }}>r_{\text {tabel }}$ sehingga item pernyataan dapat dimasukkan sebagai pedoman kuesioner.

\section{Uji Reliabilitas}

Di bawah ini merupakan hasil uji reliabilitas dengan menggunakan Statistical Product and Service Solution (SPSS) versi 21 adalah sebagai berikut:

a. Uji reliablitias Variabel LIngkungan Kerja $\left(\mathrm{X}_{1}\right)$

Tabel 8

Hasil Uji Reliabilitas Variabel Lingkungan Kerja

Reliability Statistics

\begin{tabular}{|r|r|}
\hline Cronbach's Alpha & N of Items \\
\hline .762 & 10 \\
\hline
\end{tabular}

Sumber: Hasil Olah Data SPSS 21

Berdasarkan hasil uji menggunakan SPSS 21, menunjukkan hasil uji Cronbach's Alpha sebesar 0,762, melebihi angka signifikan 0,60. Maka dapat disimpulkan bahwa variabel Lingkungan Kerja $\left(\mathrm{X}_{1}\right)$ reliable.

b. Uji reliablitias Variabel Disiplin Kerja $\left(\mathrm{X}_{2}\right)$

Tabel 9

Hasil Uji Reliabilitas Variabel Disiplin Kerja

Reliability Statistics

\begin{tabular}{|r|r|}
\hline Cronbach's Alpha & N of Items \\
\hline .782 & 10 \\
\hline
\end{tabular}

Sumber: Hasil Olah Data SPSS 21 
Berdasarkan hasil uji menggunakan SPSS 21, menunjukkan hasil uji Cronbach's Alpha sebesar 0,782, melebihi angka signifikan 0,60. Maka dapat disimpulkan bahwa variabel Disiplin Kerja $\left(\mathrm{X}_{1}\right)$ reliabel.

c. Uji reliablitias Variabel Kinerja Karyawan (Y)

Tabel 10

Hasil Uji Reliabilitas Variabel Kinerja Karyawan

Reliability Statistics

\begin{tabular}{|r|r|}
\hline Cronbach's Alpha & N of Items \\
\hline .700 & 10 \\
\hline
\end{tabular}

Sumber: Hasil Olah Data SPSS 21

Berdasarkan hasil uji menggunakan SPSS 21, menunjukkan hasil uji Cronbach's Alpha sebesar 0,700, melebihi angka signifikan 0,60. Maka dapat disimpulkan bahwa variabel Disiplin Kerja $\left(\mathrm{X}_{1}\right)$ reliabel.

\section{Uji Regresi}

Regresi sederhana digunakan untuk meramalkan atau memprediksi besaran nilai variabel terikat yang dipengaruhi oleh satu variabel bebas. Persamaan regresi sederhana dinyatakan dengan rumus sebagai berikut:

$$
\mathrm{Y}=\mathrm{a}+\mathrm{bx}
$$

1) Regresi Sederhana Lingkungan $\operatorname{Kerja}\left(\mathrm{X}_{1}\right)$ Terhadap Kinerja Karyawan (Y) Hasil pengolahan data menggunakan metode komputerisasi SPSS, maka diperoleh hasil sebagai berikut:

Regresi Variabel Lingkungan Kera $\left(\mathrm{X}_{1}\right)$ Terhadap Kinerja Karyawan (Y)

Tabel 11

Coefficients $^{\mathrm{a}}$

\begin{tabular}{|c|c|c|c|c|c|}
\hline \multirow[t]{2}{*}{ Model } & \multicolumn{2}{|c|}{$\begin{array}{l}\text { Unstandardized } \\
\text { Coefficients }\end{array}$} & $\begin{array}{l}\text { Standardized } \\
\text { Coefficients }\end{array}$ & $\mathrm{t}$ & Sig. \\
\hline & B & Std. Error & Beta & & \\
\hline (Constant) & 12.076 & 3.178 & & 3.799 & .000 \\
\hline $\begin{array}{ll}1 & \text { LINGKUNGA } \\
\mathrm{N}\end{array}$ & .709 & .080 & .793 & 8.830 & .000 \\
\hline
\end{tabular}

a. Dependent Variable: KINERJA

ber : Data primer yang diolah menggunakan SPSS, 2016

Berdasarkan tabel diatas diperoleh koefisien persamaan regresi Linear sederhana sebagai berikut:

$$
\mathrm{Y}=12,076+0,709 \mathrm{X}_{1}
$$


Penjelasan persamaan tersebut adalah sebagai berikut :

a) Konstanta sebesar 12,076 artinya jika Lingkungan kerjanilainya 0, maka tingkat Kinerja Pegawai nilainya sebesar 12,076.

b) Koefisien regresi Lingkungan kerjasebesar 0,709 artinya bila Lingkungan kerja mengalami kenaikan satu satuan maka, Kinerja karyawan akan mengalami peningkatan sebesar 0,709 satuan dengan asumsi variabel independen lainnya yang bernilai tetep.

Regresi Sederhana Disiplin Kerja $\left(\mathrm{X}_{2}\right)$ Terhadap Kinerja Karyawan (Y) Hasil pengolahan data menggunakan metode komputerisasi SPSS, maka diperoleh hasil seperti tabel di bawah ini.

Regresi Variabel Disiplin Kerja $\left(\mathrm{X}_{2}\right)$ Terhadap Kinerja Karyawan (Y)

Tabel 12

Coefficients $^{\mathrm{a}}$

\begin{tabular}{|c|c|c|c|c|c|}
\hline \multirow[t]{2}{*}{ Model } & \multicolumn{2}{|c|}{$\begin{array}{l}\text { Unstandardized } \\
\text { Coefficients }\end{array}$} & $\begin{array}{l}\text { Standardized } \\
\text { Coefficients }\end{array}$ & \multirow[t]{2}{*}{$\mathrm{t}$} & \multirow[t]{2}{*}{ Sig. } \\
\hline & B & Std. Error & Beta & & \\
\hline (Constant) & 16.714 & 3.285 & & 5.088 & .000 \\
\hline DISIPLIN & .599 & .084 & .725 & 7.131 & .000 \\
\hline
\end{tabular}

a. Dependent Variable: KINERJA

sumber: Olah Data SPSS 21, 2016

Berdasarkan tabel diatas diperoleh koefisien persamaan regresi sederhana sebagai berikut:

$$
\mathrm{Y}=16,714+0,599 \mathrm{X}_{1}
$$

Penjelasan persamaan tersebut adalah sebagai berikut :

a) Konstanta sebesar 16,714 artinya jika Disiplin Kerja nilainya 0, maka tingkat Kinerja Karyawan nilainya sebesar 16,714.

Koefisien regresi Disiplin Kerja sebesar 0,599 artinya bila Disiplin Kerja mengalami kenaikan satu satuan maka, Kinerja Karyawan akan mengalami peningkatan sebesar 0,599 satuan dengan asumsi variabel independen lainnya yang bernilai tetap.

Regresi berganda digunakan untuk meniliti apakah ada korelasi sebab akibat antara kedua variabel atau meneliti seberapa besar pengaruh antara variabel independen terhadap variabel dependen. Persamaan garis regresi ganda dinyatakan dalam rumus sebagai berikut:

$$
\mathrm{Y}=\mathrm{a}+\mathrm{b}_{1} \mathrm{X}_{1}+\mathrm{b}_{2} \mathrm{X}_{2}+\mathrm{e}
$$


Hasil pengolahan data menggunakan metode komputerisasi yaitu SPSS, maka diperoleh nilai sebagai berikut:

Regresi Variabel Lingkungan Kerja $\left(\mathrm{X}_{1}\right)$ dan Disiplin Kerja $\left(\mathrm{X}_{2}\right)$ Terhadap

Tabel 13

Kinerja Karyawan (Y)

Coefficients $^{\mathrm{a}}$

\begin{tabular}{|l|r|r|r|r|r|}
\hline Model & \multicolumn{2}{|c|}{$\begin{array}{c}\text { Unstandardized } \\
\text { Coefficients }\end{array}$} & $\begin{array}{c}\text { Standardize } \\
\mathrm{d} \\
\text { Coefficients }\end{array}$ & $\mathrm{t}$ & Sig. \\
\cline { 2 - 5 } & \multicolumn{1}{|c|}{$\mathrm{B}$} & Std. Error & Beta & & \\
\hline (Constant) & 11.817 & 3.205 & & 3.687 & .001 \\
\multirow{2}{*}{1 LINGKUN } & .899 & .245 & 1.006 & 3.669 & .001 \\
GAN & & & & & \\
DISIPLIN & -.186 & .227 & -.225 & -.821 & .416 \\
\hline
\end{tabular}

a. Dependent Variable: KINERJA

Berdasarkan tabel 4.13 yang diperoleh koefisien persamaan regersi linear berganda sebagai berikut:

$$
Y=11,817+0,899 X_{1}+-0,186 X_{2}
$$

Penjelasan persamaan tersebut adalah sebagai berikut :

1) Koefisien sebesar 11,817 artinya jika lingkungan kerja dan disiplin kerja nilainya 0 maka, tingkat kinerja karyawan nilainya sebesar 11,817.

2) Koefisien regresi variabel lingkungan kerja 0,899 artinya jika lingkungan kerja mengalami satu-satuan maka, tingkat kinerja karyawan akan mengalami peningktana sebesar 0,899 satuan dengan asumsi variabel independen lainnya yang berniali tetap.

3) Koefisien regresi variabel disiplin kerja -0,186 artinya jika disiplin kerja mengalami satu-satuan maka, tingkat kinerja karyawan akan mengalami peningktana sebesar -0,186 satuan dengan asumsi variabel independen lainnya yang berniali tetap.

\section{Uji Korelasi}

Uji korelasi sederhana digunakan untuk mengetahui kuatnya hubungan satu variabel bebas terhadap variabel terikat.

1) Uji Korelasi Kontribusi Lingkungan Kerja $\left(X_{1}\right)$ Terhadap Kinerja Karyawan(Y)

Hasil pengelolaan data menggunakan metode komputerisasi yaitu program SPSS 21, maka diperoleh hasil sebagai berikut: 
Tabel 15

KorelasiVariabel Lingkungan Kerja $\left(\mathrm{X}_{1}\right)$ Terhadap Kinerja Karyawan (Y)

Model Summary ${ }^{b}$

\begin{tabular}{|l|r|r|r|r|}
\hline Model & \multicolumn{1}{|c|}{$\mathrm{R}$} & $\mathrm{R}$ Square & $\begin{array}{c}\text { Adjusted R } \\
\text { Square }\end{array}$ & $\begin{array}{c}\text { Std. Error of } \\
\text { the Estimate }\end{array}$ \\
\hline 1 & $.793^{\mathrm{a}}$ & .629 & .621 & 3.24916 \\
\hline
\end{tabular}

a. Predictors: (Constant), LINGKUNGAN

b. Dependent Variable: KINERJA

Dari hasil perhitungan maka dapat diketahui bahwa hubungan antara Lingkungan Kerjadengan Kinerja Karyawan mempunyai tingkat hubungan yang sangat kuat yaitu 0,793

2) Uji Korelasi Kontribusi Disiplin Kerja $\left(\mathrm{X}_{2}\right)$ Terhadap Kinerja Karyawan (Y). Hasil pengelolaan data menggunakan metode komputerisasi yaitu program SPSS 21, maka diperoleh hasil yang dapat dilihat dari tabel di bawah ini.

Tabel 16

Korelasi Variabel Disiplin Kerja $\left(\mathrm{X}_{2}\right)$ Terhadap Kinerja Karyawan (Y)

Model Summary ${ }^{\mathrm{b}}$

\begin{tabular}{|l|r|r|r|r|}
\hline Model & \multicolumn{1}{|c|}{$\mathrm{R}$} & R Square & $\begin{array}{c}\text { Adjusted R } \\
\text { Square }\end{array}$ & $\begin{array}{r}\text { Std. Error of } \\
\text { the Estimate }\end{array}$ \\
\hline 1 & $.725^{\mathrm{a}}$ & .525 & .515 & 3.67597 \\
\hline
\end{tabular}

a. Predictors: (Constant), DISIPLIN

b. Dependent Variable: KINERJA

Sumber: Hasil Olah Data SPSS 21

Dari hasil perhitungan maka dapat diketahui bahwa hubungan antara Disiplin Kerja dengan Kinerja Karyawan mempunyai tingkat hubungan yang sangat kuat yaitu 0,725 .

Korelasi berganda dilakukan untuk mengetahui derajat atau kekuatan hubungan antara Lingkungan Kerja $\left(\mathrm{X}_{1}\right)$ dan Disiplin Kerja $\left(\mathrm{X}_{2}\right)$ secara bersama-sama terhadap Kinerja Karyawan (Y). Adapun uji korelasi berganda dapat dilakukan dengan cara sebagai berikut:

Hasil pengolahan data menggunakan metode SPSS, maka akan diperoleh nilai sebagai berikut:

Tabel 17

Korelasi Variabel Lingkungan Kerja $\left(\mathrm{X}_{1}\right)$ dan Disiplin Kerja $\left(\mathrm{X}_{2}\right)$ Terhadap Kinerja Karyawan (Y) 
Model Summary ${ }^{b}$

\begin{tabular}{|l|r|r|r|c|}
\hline Model & \multicolumn{1}{|c|}{$\mathrm{R}$} & $\mathrm{R}$ Square & $\begin{array}{c}\text { Adjusted R } \\
\text { Square }\end{array}$ & $\begin{array}{c}\text { Std. Error of the } \\
\text { Estimate }\end{array}$ \\
\hline 1 & $.796^{\mathrm{a}}$ & .634 & .618 & 3.26071 \\
\hline
\end{tabular}

a. Predictors: (Constant), DISIPLIN, LINGKUNGAN

b. Dependent Variable: KINERJA

Sumber: Hasil Olah Data Spss 21

Berdasarkan tabel diatas diketahui bahwa R (Korelasi) dari Variabel Lingkungan Kerjadan Disiplin Kerja terhadap Kinerja Karyawan sebesar 0,796.Jadi pengaruh antara Lingkungan Kerjadan Disiplin Kerja terhadap Kinerja Karyawan terbukti sangat kuat dengan hasil perhitungan 0,796 .

\section{Uji t (Uji Hipotesis)}

Uji t dilakukan dengan uji dua sisi dengan membandingkan $t_{\text {hitung }}$ dengan $t_{\text {tabel }}$ pada taraf signifikan 5\%. Adapun kaidah pengujian adalah sebagai berikut:

Jika nilai $t_{\text {hitung }}>t_{\text {tabel }}$, maka Ha diterima dan Ho ditolak.

Jika nilai $t_{\text {hitung }}<t_{\text {tabel }}$, maka Ho diterima dan Ha ditolak.

a. Uji t Pemberian Lingkungan Kerja $\left(\mathrm{X}_{1}\right)$ Terhadap Kinerja Karyawan (Y)

1) Hipotesis :

Ho $: r=0$ Diduga tidak terdapat Kontribusi lingkungan kerjaterhadap Kinerja kinerja karyawan PT. Gapura Angkasa Div Load Control Bandara Soekarno Hatta.

Ha $: r \neq 0$ Diduga terdapat Kontribusi lingkungan kerjaterhadap Kinerja kinerja karyawan PT. Gapura Angkasa Div Load Control Bandara Soekarno Hatta.

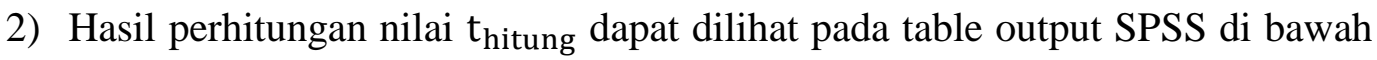
ini

Tabel 4.18

Hasil Uji t Lingkungan Kerja $\left(\mathrm{X}_{1}\right)$ dengan Kinerja Karyawan (Y)

Coefficients $^{\mathrm{a}}$

\begin{tabular}{|c|c|c|c|c|c|}
\hline \multirow[t]{2}{*}{ Model } & \multicolumn{2}{|c|}{$\begin{array}{l}\text { Unstandardized } \\
\text { Coefficients }\end{array}$} & \multirow{2}{*}{$\begin{array}{c}\text { Standardize } \\
\text { d } \\
\text { Coefficient } \\
\text { s } \\
\text { Beta }\end{array}$} & \multirow[t]{2}{*}{$\mathrm{t}$} & \multirow[t]{2}{*}{ Sig. } \\
\hline & B & Std. Error & & & \\
\hline 1 (Constant) & 12.076 & 3.178 & & $\begin{array}{r}3.79 \\
9\end{array}$ & .000 \\
\hline
\end{tabular}




\begin{tabular}{|l|l|l|l|r|r|r|}
\hline LINGKUNG & .709 & .080 & & .793 & 8.83 & .000 \\
AN & & & & 0 & \\
\hline
\end{tabular}

a. Dependent Variable: KINERJA

3) Menentukan Tingkat Signifikan Sebesar $\alpha=5 \%$ atau 0,05

$$
\begin{aligned}
& \mathrm{df}=\mathrm{n}-2 \\
& \mathrm{df}=48-2 \\
& \mathrm{df}=46 \\
& \mathrm{t}_{\text {tabel }}=(46 ; 0,05)=1,679
\end{aligned}
$$

Berdasarkan perhitungan dapat diketahui bahwa $t_{\text {hitung }} 8,830>t_{\text {tabel }}$ 1,679.Ini menunjukkan Ha diterima dan Ho ditolak.

b. Uji t Pemberian Disiplin Kerja $\left(\mathrm{X}_{2}\right)$ Terhadap Kinerja Karyawan $(\mathrm{Y})$

1) Hipotesis

Ho $: r=0$ Diduga tidak terdapat Kontribusi Disiplin Kerja terhadap Kinerja Karyawan di PT. Gapura Angkasa div. Load Control Bandara Soekarno Hatta.

Ha $: r \neq 0 \quad$ Diduga terdapat Kontribusi Disiplin Kerja terhadap Kinerja

Karyawan di PT. Gapura Angkasa div. Load Control Bandara Soekarno Hatta.

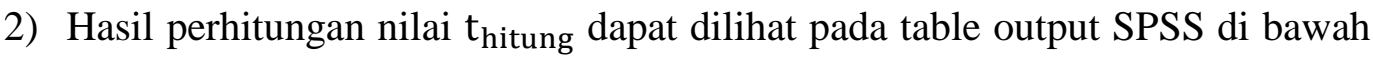

\begin{tabular}{|c|c|c|c|c|c|}
\hline \multirow[t]{2}{*}{ Model } & \multicolumn{2}{|c|}{$\begin{array}{l}\text { Unstandardized } \\
\text { Coefficients }\end{array}$} & \multirow{2}{*}{$\begin{array}{c}\text { Standardiz } \\
\text { ed } \\
\text { Coefficient } \\
\text { s }\end{array}$} & \multirow[t]{2}{*}{$\mathrm{t}$} & \multirow[t]{2}{*}{ Sig. } \\
\hline & B & Std. Error & & & \\
\hline (Constant) & 16.714 & 3.285 & & 5.088 & .000 \\
\hline DISIPLIN & .599 & .084 & .725 & 7.131 & .000 \\
\hline
\end{tabular}
ini.

Tabel 4.19

Hasil Uji t Disiplin kerja (X2)dengan Kinerja Karyawan (Y)

3) Menentukan Tingkat Signifikan Sebesar $\alpha=5 \%$ atau 0,05

$\mathrm{df}=\mathrm{n}-2$

$\mathrm{df}=48-2$

$\mathrm{df}=46$

$t_{\text {tabel }}=(46 ; 0,05)=1,679$

Berdasarkan perhitungan dapat diketahui bahwa $t_{\text {hitung }} 7.131>t_{\text {tabel }} 1,679$. Ini menunjukkan Ha diterima dan Ho ditolak.Sehingga dapat disimpulkan bahwa terdapat kontribusi lingkungan kerja terhadap kinerja karyawan di PT. Gapura Angkasa div. Load Control Bandara Soekarno Hatta. 


\section{Uji F (Simultan)}

Uji $\mathrm{F}$ dilakukan dengan membandingkan $\mathrm{F}_{\text {hitung }}$ dengan $\mathrm{F}_{\text {tabel }}$ menggunakan uji dua sisi dan dengan taraf signifikan 5\%. Adapun kaidah pengujiannya adalah sebagai berikut:

Jika nilai $\mathrm{F}_{\text {hitung }}>\mathrm{F}_{\text {tabel }}$, maka Ha diterima dan Ho ditolak

Jika nilai $\mathrm{F}_{\text {hitung }}>\mathrm{F}_{\text {tabel }}$, maka Ho diterima dan Ha ditolak

a. Hipotesis

Ho : Diduga tidak terdapat Kontribusi Disiplin Kerja terhadap Kinerja Karyawan di PT. Gapura Angkasa div. Load Control Bandara Soekarno Hatta.

Ha : Diduga terdapat Kontribusi Disiplin Kerja terhadap Kinerja Karyawan di PT. Gapura Angkasa div. Load Control Bandara Soekarno Hatta.

b. Hasil perhitungan nilai $\mathrm{F}_{\text {hitung }}$ dapat dilihat pada table output SPSS di bawah ini.

\section{Tabel 4.23}

Hasil Uji F Pengaruh Lingkungan Kerja $\left(\mathrm{X}_{1}\right)$ dan Disiplin Kerja $\left(\mathrm{X}_{2}\right)$ terhadap Kinerja Karyawan (Y)

ANOVA $^{\mathrm{a}}$

\begin{tabular}{|c|c|c|c|c|c|c|}
\hline \multicolumn{2}{|c|}{ Model } & $\begin{array}{l}\text { Sum of } \\
\text { Squares }\end{array}$ & Df & $\begin{array}{l}\text { Mean } \\
\text { Square }\end{array}$ & $\mathrm{F}$ & Sig. \\
\hline \multirow{3}{*}{1} & Regression & 830.216 & 2 & 415.108 & 39.042 & $.000^{\mathrm{b}}$ \\
\hline & Residual & 478.451 & 45 & 10.632 & & \\
\hline & Total & 1308.667 & 47 & & & \\
\hline
\end{tabular}

c. M a. Dependent Variable: KINERJA

e b. Predictors: (Constant), DISIPLIN, LINGKUNGAN

nentukan Tingkat Signifikan Sebesar $\alpha=5 \%$ atau 0,05

df $=\mathrm{n}-\mathrm{k}-1$

$\mathrm{df}=48-2-1$

$\mathrm{df}=45$

$\mathrm{F}_{\text {tabel }}=(45 ; 0,05)=3,204$

Berdasarkan perhitungan tabel di atas diketahui bahwa $F_{\text {hitung }} 39,042>F_{\text {tabel }}$ 3,204.Ini menunjukkan Ha diterimadan Ho ditolak.Ini membuktikan bahwa terdapat kontribusi Sehingga dapat disimpulkan bahwa terdapat kontribusi lingkungan kerja dan disiplin kerja secara bersama-sama terhadap kinerja karyawan di PT. Gapura Angkasa div. Load Control Bandara Soekarno Hatta. 


\section{KESIMPULAN}

1. Hasil pengujian hipotesis secara individual (Uji t) diperoleh nilai signfikan yaitu variabel Lingkungan Kerja sebesar 0.000 lebih kecil dari 0.05 yang berarti Lingkungan Kerja berkontribusi signifikan terhadap Kinerja Karyawan. Dan hasil pengujian (Uji f) ada pengaruh yang positif dan signifikan antara lingkungan kerja terhadap kinerja karyawan PT. Gapura Angkasa Div Load Control sebesar 62.9\% dan sisanya 37.1\% menjelaskan bahwa kinerja karyawan dipengaruhi oleh faktor-faktor lain diluar lingkungan kerja.

2. Hasil pengujian hipotesis secara individual (Uji t) diperoleh nilai signfikan yaitu variabel Disiplin Kerja sebesar 0.000 lebih kecil dari 0.05 yang berarti Disiplin Kerja berpengaruh signifikan terhadap Kinerja Karyawan. Dan hasil pengujian (Uji f) ada pengaruh yang positif dan signifikan antara disiplin kerja terhadap kinerja karyawan PT. Gapura Angkasa Div Load Control sebesar 52.5\% dan sisanya 47.5\% menjelaskan bahwa kinerja karyawan dipengaruhi oleh faktor-faktor lain diluar disiplin kerja

3. Hasil pengujian secara simultan menunjukan nilai signifikasi sebesar 0.000 lebih kecil dari 0.05. hal ini mengandung arti bahwa terdapat kontribusi. sehingga dapat disimpulkan bahwa terdapat kontribusi lingkungan kerja dan disiplin kerja secara bersama-sama berpengaruh terhadap kinerja karyawan di PT. Gapura Angkasa div Load Control. Dan hasil pengujian (Uji f) ada pengaruh yang positif dan signifikan antara lingkungan kerja dan disiplin kerja terhadap kinerja karyawan PT. Gapura Angkasa Div Load Control sebesar $63.4 \%$ dan sisanya $36.6 \%$ menjelaskan bahwa kinerja karyawan dipengaruhi oleh faktor-faktor lain diluar lingkungan kerja dan disiplin kerja.

\section{DAFTAR PUSTAKA}

[1] Irianto Agus. Statistik :Konsep Dasar dan Aplikasinya.Prenada Media Jakarta. 2011

[2] Sugiyono. Metode penelitian Administrasi. Penerbit Alfabeta. Bandung 2015

[3] Suwarto, FX. Perilaku Keorganisasian. Penerbit Universitas Atma Jaya, Yogyakarta. 2015

[4] Dahlan Siamat. 2011. Managemen Lembaga Keuangan Kebijakan Moneter dan Perbankan.Edisi ke lima. Jakarta : Fakultas Ekonomi Universitas Indonesia

[5] Samsul, 2012. Pasar Modal \& Manajemen Portofolio, Edisi Pertama. Jakarta : Erlangga

[6] Rahman, Harif. 2011. Pengaruh economic value added (EVA), return on asset (ROA), dan persentase kepemilkan modal saham asing terhadap harga saham pada perusahaan perbankan yang terdaftar di Bursa Efek Indonesia (BEI). Tesisdipublikasikan.Universitas Negeri Padang.

[7] Hakim, L., 2016 Epidemiologi Infeksi Menular Seksual. In Daili, S.F.et al., Infeksi Menular Seksual $4^{\text {th }}$ ed Jakarta: Balai penerbitan FKUI, 3-16

[8] Anwar, A 2010 Pengantar pendidikan kesehatan Jakarta PT Sasstra Hudaya

[9] Ridwan. 2013. Manajemen Waktu dan Manajemen Kontrol 